\title{
Non-Equilibrium Thermodynamics of Micro Technologies
}

\author{
Mohsen Torabi ${ }^{1,2, *}$, Nader Karimi ${ }^{3,4, *(D)}$, Mostafa Ghiaasiaan ${ }^{1, *}$ and Somchai Wongwises ${ }^{5, *}$ \\ 1 The George W. Woodruff School of Mechanical Engineering, Georgia Institute of Technology, Atlanta, \\ GA 30332, USA \\ 2 School of Engineering, University of California, Merced, CA 95343, USA \\ 3 School of Engineering, University of Glasgow, Glasgow G12 8QQ, UK \\ 4 School of Computing and Engineering, Civil and Mechanical Engineering Department, \\ University of Missouri-Kansas City, Kansas City, MO 64110, USA \\ 5 Department of Mechanical Engineering, King Mongkut's University of Technology Thonburi, \\ Bangkok 10140, Thailand \\ * Correspondence: Mohsen.Torabi@my.cityu.edu.hk (M.T.); Nader.Karimi@glasgow.ac.uk (N.K.); \\ mghiaasiaan@me.gatech.edu (M.G.); somchai.won@kmutt.ac.th (S.W.)
}

Received: 13 May 2019; Accepted: 13 May 2019; Published: 17 May 2019

Abstract: This is the Editorial article summarizing the scope and contents of the Special Issue, Non-Equilibrium Thermodynamics of Micro Technologies.

Keywords: entropy generation; micro thermofluidic systems; micro channels; miniaturized cryocoolers; micro reactors

\section{Second Law of Thermodynamics and Its Importance in Microscale Systems}

Advancement of manufacturing techniques has resulted in a significant reduction in the size of the individual components within many devices. This advancement has put forward micro and nanoscale devices instead of macroscale counterparts. Miniaturized thermofluidic systems are a subcategory of this renovation, and has recently gained significant attention. Applications of these systems in micro manufactured devices is growing steadily. Some emerging applications of micro thermofluidic systems include, microreactors $[5,6]$, micro heat sinks $[7,8]$, and micro cryocoolers $[9,10]$, to name a few. The progresses in the design, development and application of micro thermofluidic systems have resulted in high demand for their heat transfer and thermodynamics analyses. Hence, small-scale thermofluidic systems have been the subject of both theoretical and experimental investigations [1-4].

Scholars have tried to investigate these systems for years from the heat transfer perspectives and so far a number of reviews have appeared in connection with these systems $[2,11]$. With regards to the first law of thermodynamics and its application to the performances of these systems, temperature simulation [12] and visualization [13], heat flux investigation and optimization [14,15], and partial or total design reconfigurations [16-18] have been performed.

Recently, micro thermal systems have gained attention regarding the second law's performance and researchers have started to focus on investigating micro thermal systems from the entropy perspective $[19,20]$. The second law analysis is a quantitative approach to evaluate the efficiency of thermofluidic systems [21]. The second law analysis provides scholars a tool to minimize the irreversibility of the system, and hence results in more environmentally friendly systems [22]. Regarding small scale thermofluidic systems, the second law investigations range from entropy generation in micro-channels [20-23] and concentric micro-fin tube heat exchanger [24] to micro combustors [25,26] and micro reactors $[27,28]$. To perform the second law analysis, various effects and specifications of the system including, but not limited to, fluid flow, heat and mass transfer, internal heat generation 
and electromagnetic effects should be included within analyses. There are relatively large number of textbooks which covers the concept of the second law analysis in thermofluidic systems [21,29-31]. However, because of rapid development of small-scale systems, there is an urgent need to perform more investigations on more diverse applications such as microreactors, micro-scale thermoelectric coolers, and new geometries of microchannels. The main motivation for this special issue is to diversify the available literature regarding the second law of thermodynamics in microscale thermofluidic system by contributing nine articles.

\section{The 9 Contributions Published in This Special Issue}

This special issue consists of nine articles that report on investigations dealing with heat and mass transfer and thermodynamic analysis of thermofluidic systems [32-40]. Most of these investigations are analytic or numerical [32-40]. Two of the investigations include experiments [36,39]. The main theme of four articles in this special issue is optimization of microchannels from both energetic and entropic perspectives $[34,36,39,40]$. Other areas that have been explored include the analysis and optimization of microreactors [33], simulation and thermal analysis of micro circular Couette flow [37], and thermodynamic analysis of various-shaped micro-scale thermoelectric coolers [38]. Moreover, an interesting concept named virtual entropy generation method has been elaborated by Zhang et al. [35], which provides a path for the evaluation of leakage in channels using the concept of entropy generation.

Thermodynamic analysis of micro thermofluidic systems is an emerging area. With the advancement of manufacturing techniques and rapid growth of micro-fabricated devices, design and optimization of small-scale thermofluidic systems need more attention. This special issue is one step towards this goal, and it is hoped that it will inspire further investigations.

Acknowledgments: We would like to thank the contributing authors and the editorial staff of Entropy who made this special issue possible. We also greatly appreciate the anonymous reviewers for their invaluable time and effort. This special issue could not have materialized without them.

Conflicts of Interest: The authors declare no conflict of interest.

\section{References}

1. Suryawanshi, P.L.; Gumfekar, S.P.; Bhanvase, B.A.; Sonawane, S.H.; Pimplapure, M.S. A review on microreactors: Reactor fabrication, design, and cutting-edge applications. Chem. Eng. Sci. 2018, 189, 431-448. [CrossRef]

2. Kaisare, N.S.; Vlachos, D.G. A review on microcombustion: Fundamentals, devices and applications. Prog. Energy Combust. Sci. 2012, 38, 321-359. [CrossRef]

3. Samiei, E.; Tabrizian, M.; Hoorfar, M. A review of digital microfluidics as portable platforms for lab-on a-chip applications. Lab Chip 2016, 16, 2376-2396. [CrossRef] [PubMed]

4. Awad, M.M. A review of entropy generation in microchannels. Adv. Mech. Eng. 2015, 7. [CrossRef]

5. Mies, M.J.M.; Rebrov, E.V.; Deutz, L.; Kleijiv, C.R.; De Croon, M.H.J.M.; Schouten, J.C. Experimental validation of the performance of a microreactor for the high-throughput screening of catalytic coatings. Ind. Eng. Chem. Res. 2007, 46, 3922-3931. [CrossRef]

6. Hunt, G.; Torabi, M.; Govone, L.; Karimi, N.; Mehdizadeh, A. Two-dimensional heat and mass transfer and thermodynamic analyses of porous microreactors with Soret and thermal radiation effects-An analytical approach. Chem. Eng. Process Process Intensif. 2018, 126, 190-205. [CrossRef]

7. Zhai, Y.; Xia, G.; Chen, Z.; Li, Z. Micro-PIV study of flow and the formation of vortex in micro heat sinks with cavities and ribs. Int. J. Heat Mass Transf. 2016, 98, 380-389. [CrossRef]

8. Xia, G.; Ma, D.; Zhai, Y.; Li, Y.; Liu, R.; Du, M. Experimental and numerical study of fluid flow and heat transfer characteristics in microchannel heat sink with complex structure. Energy Convers. Manag. 2015, 105, 848-857. [CrossRef]

9. Champagne, P.; Olson, J.R.; Loung, V.; Dobbins, C.L.; Saito, E.; Kenton, A.C.; Dobbins, C.L. Microcryocooler for tactical and space applications. Adv. Cryog. Eng. 2014, 357, 357-364. [CrossRef] 
10. Cao, H.S.; Vanapalli, S.; Holland, H.J.; Vermeer, C.H.; ter Brake, H.J.M. A micromachined Joule-Thomson cryogenic cooler with parallel two-stage expansion. Int. J. Refrig. 2016, 69, 222-231. [CrossRef]

11. Wang, K.; Vafai, K.; Wang, D. Analytical characterization of gaseous slip flow and heat transport through a parallel-plate microchannel with a centered porous substrate. Int. J. Numer. Methods Heat Fluid Flow 2016, 26, 854-878. [CrossRef]

12. Lee, J.; Mudawar, I. Fluid flow and heat transfer characteristics of low temperature two-phase micro-channel heat sinks-Part 1: Experimental methods and flow visualization results. Int. J. Heat Mass Transf. 2008, 51, 4315-4326. [CrossRef]

13. Li, J.; Chou, S.K.; Li, Z.W.; Yang, W.M. Experimental investigation of porous media combustion in a planar micro-combustor. Fuel 2010, 89, 708-715. [CrossRef]

14. Ling, L.; Zhang, Q.; Yu, Y.; Wu, Y.; Liao, S.; Sha, Z. Simulation of a micro channel separate heat pipe (MCSHP) under low heat flux and low mass flux. Appl. Therm. Eng. 2017, 119, 25-33. [CrossRef]

15. Abdoli, A.; Jimenez, G.; Dulikravich, G.S. Thermo-fluid analysis of micro pin-fin array cooling configurations for high heat fluxes with a hot spot. Int. J. Therm. Sci. 2015, 90, 290-297. [CrossRef]

16. Zhang, K.; Chou, S.K.; Ang, S.S. Fabrication, modeling and testing of a thin film Au/Ti microheater. Int. J. Therm. Sci. 2007, 46, 580-588. [CrossRef]

17. Li, T.; Wu, L.; Liu, Y.; Wang, L.; Wang, Y.; Wang, Y. Micro-heater on membrane with large uniform-temperature area. In Proceedings of the 2006 IEEE Sensors Conference, Daegu, South Korea, 22-25 October 2006; pp. 571-575.

18. Gupta, N.K.; Gianchandani, Y.B. Porous ceramics for multistage Knudsen micropumps-Modeling approach and experimental evaluation. J. Micromech. Microeng. 2011, 21, 095029. [CrossRef]

19. Pang, L.; Wang, M.; Wang, W.; Liu, M.; Wang, J. Optimal thermal design of a stacked mini-channel heat sink cooled by a low flow rate coolant. Entropy 2013, 15, 4716-4731. [CrossRef]

20. Ting, T.W.; Hung, Y.M.; Guo, N. Entropy generation of nanofluid flow with streamwise conduction in microchannels. Energy 2014, 64, 979-990. [CrossRef]

21. Bejan, A. Entropy Generation Through Heat and Fluid Flow; Wiley: New York, NY, USA, 1982.

22. Dinçer, I.; Zamfirescu, C. Sustainable Energy Systems and Applications; Springer: Berlin/Heidelberg, Germany, 2011.

23. Elazhary, A.M.; Soliman, H.M. Entropy generation during fully-developed forced convection in parallel-plate micro-channels at high zeta-potentials. Int. J. Heat Mass Transf. 2014, 70, 152-161. [CrossRef]

24. Naphon, P. Study on the exergy loss of the horizontal concentric micro-fin tube heat exchanger. Int. Commun. Heat Mass Transf. 2011, 38, 229-235. [CrossRef]

25. Jiang, D.; Yang, W.; Chua, K.J. Entropy generation analysis of $\mathrm{H}_{2}$ /air premixed flame in micro-combustors with heat recuperation. Chem. Eng. Sci. 2013, 98, 265-272. [CrossRef]

26. Jiang, D.; Yang, W.; Chua, K.J.; Ouyang, J.; Teng, J.H. Analysis of entropy generation distribution in micro-combustors with baffles. Int. J. Hydrogen Energy 2014, 39, 8118-8125. [CrossRef]

27. Elliott, A.; Torabi, M.; Karimi, N. Thermodynamics analyses of porous microchannels with asymmetric thick walls and exothermicity: An entropic model of microreactors. J. Therm. Sci. Eng. Appl. 2017, 9, 041013. [CrossRef]

28. Hunt, G.; Karimi, N.; Torabi, M. Analytical investigation of heat transfer and classical entropy generation in microreactors-The influences of exothermicity and asymmetry. Appl. Therm. Eng. 2017, 119, 403-424. [CrossRef]

29. Thess, A. The Entropy Principle; Springer: Berlin/Heidelberg, Germany, 2011.

30. Naterer, G.F.; Camberos, J.A. Entropy-Based Design and Analysis of Fluids Engineering Systems; CRC Press: Boca Raton, FL, USA, 2008.

31. Bejan, A. Entropy Generation Minimization: The Method of Thermodynamic Optimization of Finite-Size Systems and Finite-Time Processes; CRC Press: Boca Raton, FL, USA, 1995.

32. Khan, A.; Abro, K.A.; Tassaddiq, A.; Khan, I. Atangana-Baleanu and Caputo Fabrizio analysis of fractional derivatives for heat and mass transfer of second grade fluids over a vertical plate: A comparative study. Entropy 2017, 19, 279. [CrossRef]

33. Govone, L.; Torabi, M.; Hunt, G.; Karimi, N. Non-equilibrium thermodynamic analysis of double diffusive, nanofluid forced convection in catalytic microreactors with radiation effects. Entropy 2017, 19, 690. [CrossRef] 
34. Wang, R.; Wang, W.; Wang, J.; Zhu, Z. Analysis and optimization of trapezoidal grooved microchannel heat sink using nanofluids in a micro solar cell. Entropy 2018, 20, 9. [CrossRef]

35. Zhang, Z.; Drapaca, C.; Zhang, Z.; Zhang, S.; Sun, S.; Liu, H. Leakage evaluation by virtual entropy generation (VEG) method. Entropy 2018, 20, 14. [CrossRef]

36. Ternet, F.; Louahlia-Gualous, H.; Le Masson, S. Impact of microgroove shape on flat miniature heat pipe efficiency. Entropy 2018, 20, 44. [CrossRef]

37. Mondal, P.K.; Wonwises, S. Assesment of thermodynamic irreversibility in a micro-scale viscous dissipative circular couette flow. Entropy 2018, 20, 50. [CrossRef]

38. Badillo-Ruiz, C.; Olivares-Robles, M.; Ruiz-Ortega, P. Performance of Segmented Thermoelectric Cooler Micro-Elements with Different Geometric Shapes and Temperature-Dependent Properties. Entropy 2018, 20, 118. [CrossRef]

39. Shui, L.; Sun, J.; Gao, F.; Zhang, C. Flow and Heat Transfer in the Tree-Like Branching Microchannel with/without Dimples. Entropy 2018, 20, 379. [CrossRef]

40. Deng, D.; Pi, G.; Zhang, W.; Wang, P.; Fu, T. Numerical Study of Double-Layered Microchannel Heat Sinks with Different Cross-Sectional Shapes. Entropy 2018, 21, 16. [CrossRef]

(C) 2019 by the authors. Licensee MDPI, Basel, Switzerland. This article is an open access article distributed under the terms and conditions of the Creative Commons Attribution (CC BY) license (http://creativecommons.org/licenses/by/4.0/). 